American Journal of Economics and Business Administration 3 (3): 450-455, 2011

ISSN 1945-5488

(C) 2011 Science Publications

\title{
Persistence of Traditional Retailing in an Island Town
}

\author{
${ }^{1}$ S. Selvadurai, ${ }^{2}$ R. Moorthy, ${ }^{1}$ N. Lyndon and ${ }^{1}$ A.C. Er \\ ${ }^{1}$ School of Social, Development and Environmental Studies, \\ ${ }^{2}$ School of History, Politics and Strategy, Faculty of Social Sciences and Humanities, \\ University Kebangsaan Malaysia, Bangi 43600, Selangor, Malaysia
}

\begin{abstract}
Problem statement: The convergence of modern retail formats in the developing world is resisted by the persistence of traditional retail formats. The issue of lower-circuit and middle-circuit in traditional retail trade in the modernizing urban arena has raise debates about its co-existence in different cultural and geographical settings. The aim of this study is to examine the persisting organizational features of sundry and general store retail trade in Labuan town, East Malaysia. Approach: A descriptive design using qualitative approach is utilized. Data is collected from a series of recursive informal interview from a total of 14 sundry and general retailers. Data is analyzed from themes derived from narrative account. Results: The findings reveal that the persistence of traditional retailing can be characterized by family business and the stability of sole proprietorship, coupled with the prevalence of independent outlets. The reasons attributed to the persistence of traditional retailing are a combination of organizational capacity factors of the retail traders and the situational context of the island economy. Conclusion: Island towns have a unique capacity to preserve certain retail trades that are under threat in conventional geographical context. This implies that the island with porous borders, not only have a confluence of external influence, but can sustain economic cultures. Future research can explore the persistence of cultural goods in these sundry and general stores to see the extent to which diverse socio-economic market structures are served.
\end{abstract}

Key words: Traditional retailing, island town, economic development, pre-modern institutions, island economy, family business

\section{INTRODUCTION}

Economic development can be viewed as part of a broad process of cultural transformation in which cities and towns act as agents of change. As such cities become a tool of modernization and this approach has been the mainstay of development approach in developing economies, particularly in Southeast Asia. Contemporary modernization theory views economic development as a part of the larger process of social and cultural change (Qadeer, 1974; Ramezani and Hamidi, 2010). Modernization as a transformation of traditional or pre-modern institutions posits a new formation of social organization characterized by advancement in technological and institutional capability. The dualist notion of transformation from a traditional to modern entity, as well as its co-construct rural to urban is contested by some modernist as inappropriate, as one can modernize and still persist with traditional values and practices (Marglin and Marglin, 1990; Smelser and Swedberg, 1994; Smelser and Swedberg, 1994).
Inglehart and Baker (2000) has framed this debate in the socioeconomic development literature as the convergence versus persistence school, emphasizing the convergence of modernization values and institutions in the former and depicting the persistence of traditional forms in the latter.

Urban retailing in developed and developing economies houses both traditional and modern retailing. Traditional retailing is characterized by traditional retail formats (i.e., personal service), is managed by families, owned by a sole proprietor or independents and often involves small-scale enterprises (Selvadurai, 2003; CCRRCA, 2007). We have classified the traditional retailing as covering a range of activities in the lowercircuit sector and the middle-circuit sector. The lowercircuit sector is the impermanent informal sector such as traditional food vendors, hawkers, wet markets, periodic markets, bazaar. Whilst the middle-circuit sector within the traditional retailing format entails permanent and formal stores with traditional features such as family, independent and small outlets. There are

Corresponding Author: S. Selvadurai, School of Social, Development and Environmental Studies, University Kebangsaan Malaysia, Bangi 43600, Selangor, Malaysia Tel: 603-89213922 Fax: 603-89213334 
many types of trades engaged by the traditional middlecircuit sector such as sundry, general store, textile and clothing. Caution should be noted of the existence of hybrid middle-circuit sector where the retail formats can be family owned, self-service and multiple ownership structure such as partnership venture (Selvadurai, 2003). Meanwhile modern retail stores are self-service offerings that typically are part of a chain of stores and belong to an organization that has a corporate structure (CCRRCA, 2007). The sundry and general store refers to small-scale permanent stores offering a variety of merchandise or range of different or unrelated types of goods and services.

In the past, studies on urban commercial and retail activities in developing countries by foreign scholars have concentrated on the persistence notion of exotic nature of the informal sector or the lower circuit of the urban economy (Geertz, 1963; Moir, 1978; Evers, 1981; Evers, 1994; Peattie, 1987; Benton, 1989; Sethuraman, 1998; Thomas, 1995; Walsh, 2010). These studies have neglected other formal retail activity such as permanent stores (i.e., in shophouse premise) that have sustained in the wider spectrum of retail activity (Potter and Salau, 1990; Selvadurai, 2003). In a similar vein, contemporary and recent studies tend to focus on modern retail formats such as supermarkets, specialty stores, department stores, shopping centers and hypermarket retail development (Goldman, 1981; 1982; 2001; Kaliappan et al., 2009; Bidyarthi et al., 2011). There were two streams of studies that have emerged from these modernizing retail studies in developing countries: (i) internationalization and entry of foreign large retailers into these countries and (ii) impact of large-scale retailing (i.e., supermarket, hypermarket) on small traders and local consumers. Both these stream of studies tend to overemphasize and reinforce the convergence school argument.

However, the persistence school idea in the middle circuit retail activities has emerged as a vibrant discourse in the developed world (Covin and Miles, 1999; Crewe and Forster, 1993; Wrigley and Lowe, 1996, 1996; Crewe, 1996; Stone, 1995; Worthington, 1998; Hallsworth and Worthington, 2000). The persistence schools have also emerged in the developing world, but in a mixed fashion. The counter trends were observed in the fresh food sector and certain complementary retail trades. Studies by Findlay et al. (1990); Chamhuri and Batt (2009); Goldstein (1990) and Goldman et al. (1999) showed that wet market traditional retail formats still dominate the fresh food arena in Malaysia, Taiwan and Hong Kong respectively, even though supermarkets have made inroads into the retail landscape for a long time. A local study undertaken by Kaliappan et al. (2009) found that complementary type of small retail businesses benefitted from the presence of foreign hypermarkets whilst small grocers were negatively impacted. Others such as Selvadurai (2003) and Roslin and Melewar (2008) found that small retailers possess distinctive qualities that differentiate their provision from large retailers. This persistence of small retailers suggests that historical, cultural and geographical context (such as island towns) manifest different trade product provision responses. In a similar vein but in broader retail geographical literature, Findlay et al. (1990) argued for the need to understand why places in different culture and areas evolve distinctive retail structures and how its changes are reflective of the urban environment.

Island towns in small island economies are somewhat different from their counterpart on mainland towns, in that it has been characterized by its inherent external dependent structure and spatial impediments (Selvadurai, 2003). This external dependent structure was influenced by its dependence on development capital (i.e., central government assistance and initiatives), consumer markets (i.e., tourist market) and economic investment (Poirine, 1993; Zhang, 1994; Bertram, 1993). This dependence structure suggests a loss of control on the locality to shape its development path. Meanwhile the spatial impediments of island towns are faced with isolation, inaccessibility and higher cost inputs (Bertram, 1993). Besides these geographical constraints, island economies and towns are also opportune by the open border and fluid nature that enabled prospective tourist resource ventures (i.e., island attraction, water sports) as well as illegal activities (i.e., smuggling trade) (Selvadurai, 2003; Selvadurai et al., 2011). An island economy with dramatic urban restructuring like Labuan provides an excellent site to examine the persistence of traditional retailing such as sundry and general store trade.

The literature was scarce on the persistence of traditional retail characterized by independent, smallscale, formal and permanent retail stores. Sundry and general store retailing has been part of the Malaysian retail fabric from the early town centre location and its continued presence in the suburban and neighborhood locations. More so, few studies have examined the persistence sundry and general store in island towns, particularly in the developing world, which this study attempts to fill the gap. Thus, the aim of this study is to examine the persisting organizational features of sundry and general store retail trade in Labuan town, East Malaysia. 
Am. J. of Economics and Business Administration 3 (3): 450-455 2011

\section{MATERIALS AND METHODS}

Site description: Labuan Island has undergone several changes in its structures of governance, from the colonial occupation, to provincial state government (i.e., Sabah) and finally under the Federal Government rule (i.e., Federal Territory). Changes in governance have led to changes in economic representation from a barter trade post in the 1970s to a free port status in 1984 and as an International Offshore Financial Centre (IOFC) status in 1990. However the economic structure of the island was dominated by the public service sector, followed by manufacturing sector and in the wholesale, retail, hotels and restaurants sector. To complement the financial business, the government have been promoting the business and shopping as tourism attraction. The Labuan island population stands at about an estimated 85000 people in 2009, with 54752 people in Labuan town GeoName.

Data collection and analysis: A descriptive design using qualitative approach was utilized. Data were collected from series of recursive informal interview exercise (Khairul, 2008) conducted since 1997, with follow up interviews conducted in 2003 and 2005. The sundry and general store trade was chosen because it is one of the major retail trades in Labuan town. A total of 14 informal interviews on the sundry and general store trade were obtained, after narratives on features and reasons on sundry and general store pattern appears saturated. Interview data on the persistence of sundry and general store trade was focused on organizational features such as family attributes, ownership structure, retail formats and other structural questions were sought. Besides that reasons for the persistence of traditional retailing was sought. Data were analyzed thematically (Novel et al., 2011) by examining the organizational features of their retail trade, as well as to elicit reasons for the persistence of the sundry and general store trade.

\section{RESULTS}

Family business: One of the prevalent features of traditional retailing in the sundry and general store retail trade was the family business operation. The term family business here refers not only to family ownership, but also to participation by family members in the operation of their business. The family business was not only common among the independent type of organizations but also among the multiples. Multiples refer to enterprises having more than one establishment as part of their enterprises.
This suggests that even in business expansion conditions the family structure plays a prominent role. Another feature of the traditional retailing was that older business establishments (i.e., more than 12 years old) were more likely to be family operated than were newer establishments, reinforcing the sustenance of such activities.

Most of the family businesses are patriarchal in nature, operated by fathers and then subsequently taken over by their sons. This pattern holds in the predominantly Chinese operated sundry and general stores. Before the $1990 \mathrm{~s}$ core family members participated in the business, namely sons, brothers and wives of the owner-managers. Over time, the circle of family members involved has grown and in the 2000s included daughters, sisters, mothers, cousins and inlaws. This 'widening' participation of family members was the result of: (i) Labor shortages in the locality, (ii) Greater trust in family members, (iii) Exposure of family members to entrepreneurial skills, (iv) Engaging more educated family members in their enterprise and (v) Keeping up with changes in technology such as computers or mobile computing (Suman and Psunder, 2007), with which younger generations within the family are most familiar. Thus adaptation process within the traditional retailing such as the sundry sector saw some moving into modern self-service format along the minimarket concept, though they are not many.

The Chinese families' participation in family retail business is unique in several points. The local Chinese have limited family ties to mainland China and use domestic family members in their enterprises. As such they utilize both sexes in their enterprises. The Chinese businesses are more inclined to utilize narrower kinship ties in business participation and succession. Besides that, they use dialects and clans as social capital to establish ties in business. In contrast, the Indians (mainly local born) and Malays are new entrants into the sundry urban sector (i.e., permanent retailing) and utilize nuclear family members and external workforce.

Independent character: As alluded earlier, the prevalence of independent organization amongst family businesses is a feature of traditional retailing, which has persisted over time. Independent stores were more common amongst the medium-aged and older stores in the sundry and general store retail trade. The medium and older establishments in those trades are also predominantly family operated. This suggests that the medium and older independent stores have not expanded. 
To illustrate an examples an independent retailer 'XX Minimart,' who commenced operation in 1971 as a general store by the father of the present retailer, who also owns the premises. Later the son (the current owner-manager) who had worked under his father's apprenticeship took over the business in 1976 as a result of his father's ill health. Subsequently, the retailer, a local Chinese from the Hokkien-clan, introduced the new self-service concept and reformed the store as an independent mini-market general store. He considered the period between 1976 until 1982 as the "best years (sales)...because he was one of the leaders in the mini-market concept." However, he has maintained the same old structures until now, with few modifications. For example, the arrangements and shelf structures do not reflect the latest mini-market retail format, as observed in other establishments. The retailer also noted that since 1994 his sales "had declined," but the business is "surviving" because he does not have to incur high overheads, as the premise was privately owned. He has no plans to expand because of the capacity constraints of the mini-market and size of premises, as well as the broader slowdown in the general store business due to competition from the opening of larger supermarkets and wholesaleretailers. This store like other sundry and general store continue to operate as an independent smallscale activity because of constraints island market, restraining further expansion.

Ownership structure: Partnership and sole proprietorship arrangements characterized older sundry and general stores. Sole proprietorship tended to last over time in the sundry and general store retail trades, where changes in business ownership were relatively lower. The stability of sole proprietorship ownership structure in the sundry and general stores suggests strong family tradition in continuing such businesses. Many retailers have ventured into partnership with nonfamily entities but have complained that such enterprise does not last long. Even partnerships with family members have not been successful for example amongst brothers in a case of a sundry retail that lasted for two years. Thus the prevalent feature of sole proprietorship and its small-size independent and family character The stability in these ownership structures is both due to internal constraints such as capital and information, as well as sustenance of these activities for survival purposes.

\section{DISCUSSION}

There are several reasons that can be attributed for the persistence of traditional organization feature of sundry and general store retailing in Labuan, namely the easy start-up or incubation of the trade, the generational comfort and survival intent, the expandability constraint, the island's economic conditions and its historical embeddedness. The prevalence of small independent sundry stores operated by family business as can be attributed to the ease of entry for family capital as well as traders engaged in barter trade in the island economy. This trend suggests the prevalence of family operation as an "incubator enterprise" for intergenerational transfer of enterprise culture. Besides that employee commitment to small business is much higher as shown in organizational behavior studies (Muthuveloo and Rose, 2005)

The generational comfort and survival intent of these retailers were shaped by the social and cultural embeddedness of these retailers who resist change especially in stores that are family run independent stores. Likewise, established business ties, fear of venturing into new methods or techniques, lack of education (Moorthy et al., 2011) and lack of contacts in reforming business all have a stabilizing effect. Another critical factor is that older establishments have less overheads commitment, since these retailers own the premise and the sundry retail option remains a favorite amongst the older generation.

The expandability constraint reflected in the continued independent character of these retailers can be attributed to combination of several inter-related factors: Limited capital; family operation; sole proprietorship ownership structures; the nature of the trade; the slowdown in the local economy; declining consumer market and the constraint of the small island market. The island economic conditions such as slowdown in its economy and increased operating costs (i.e., rental rates, freight charges, surge in rental property) have prompted retailers to continue on existing retail format. Also the predominantly rural structure of the island economy prompted family and independent retailers to continue in such enterprise. Even under modernizing conditions of the industrial and financial development, the prevalence of the migrant workers, neighboring tourist market sustained such enterprise.

The historical embedding of the sundry and general stores trades has a wider link with the barter trade activity of Labuan. Labuan was a free port, dealing in barter trade, mainly engaged in manufactured goods. As such, most of the small retailers are engaged in those trades proliferated as a result of the spin-off generated by the barter trade and the volume of trading providing the economies of scale for them to sustain. Though the barter trade has dwindled the historical institutional process persists. This trend of pathway 
dependency resonates with the view expressed by Findlay et al. (1990) that emphasized the distinctive social and institutional context in which retailing occurs in developing world, as illustrated in the experience of the island town of Labuan.

\section{CONCLUSION}

By way of conclusion, the persistence of traditional retailing was characterized by inherent family business and stability of sole proprietorship, coupled with the prevalence of independent outlets. The island towns with its structural dependency have a unique capacity to preserve certain retail trades that are under threat in conventional geographical context. The reasons attributed to the persistence of traditional retailing are a combination of retailer capacity factors and the situational context of the island economy. This implies that the island with porous borders, not only have a confluence of external influence, but can sustain economic culture. The historical regional link, local social and cultural embeddedness and the limited market of the island economy, places constraints to small sundry and general store traders in persisting in existing organization form.

Future research can explore the persistence of cultural goods in these sundry and general stores, to see the extent to which diverse socio-economic market structures are served. Furthermore, studies on other traditional retailing offering comparison goods trades such as textile and clothing sector which forms a prevalent feature of urban areas in the developing world will be an interesting exposition. These essential retail trades were often linked to the urban economic history and will reveal different levels of persistence, in view of the competition from modern retail structures such as hypermarket and department store formats.

\section{REFERENCES}

Benton, L.A., 1989. The Informal Economy: Studies in Advanced and Less Developed Countries. 1st Edn., John Hopkins University Press, Baltimore, ISBN: 9780801837364, pp: 327.

Bertram, G., 1993. Sustainability, aid, and material welfare in small south pacific island economies. World Dev., 21: 247-258. DOI: 10.1016/0305750X(93)90020-A

Bidyarthi, H.M.J., A.K. Srivastava, P.V. Bokad and M.A. Dande, 2011. From subhiksha (prosper) to iksha (perspire): The topsy-turvy story of Indian retail business model. Am. J. Econ. Bus. Admin., 2: 153-156. DOI: 10.3844/ajebasp.2010.153.156
CCRRCA, 2007. Food Retail Formats in Asia Understanding Format Success.

Chamhuri, N. and P.J. Batt, 2009. Consumer choice of retail outlet: focus group interviews in Malaysia. Acta Horticulturae, 831: 237-246.

Covin, J.G. and M.P. Miles, 1999. Corporate entrepreneurship and the pursuit of competitive advantage. Entrepreneurship: Theory Practice, 23: 47-63.

Crewe, L. and Z. Forster, 1993. Markets, design, and local agglomeration: The role of the small independent retailer in the workings of the fashion system. Environ. Plann. D. Soc. Space, 20: 213229. DOI: $10.1068 / \mathrm{d} 110213$

Crewe, L., 1996. Material culture: Embedded firms, organizational networks and the local economic development of a fashion quarter. Reg. Stud., 30: 257-272. DOI: 10.1080/00343409612331349618

Evers, H.D., 1981. The contribution of urban subsistence production to incomes in Jakarta. Bull. Indonesian Econ. Stud., 17: 89-96. DOI: 10.1080/00074918112331334009

Evers, H.D., 1994. The Moral Economy of Trade: Ethnicity and Developing Markets. 1st Edn., Routledge, London, ISBN: 0415092906, pp: 271.

Findlay, A.M., R. Paddison, J.A. Dawson, 1990. Retailing Environments in Developing Countries. 1st Edn., Routledge, London, ISBN: 0415037395, pp: 284.

Geertz, C., 1963. Peddlers and Princes: Social Change and Economic Modernization in two Indonesian Towns. 1st Edn., University of Chicago Press, Chicago, ISBN: 0226285146, pp: 172.

Goldman, A., 1981. Transfer of retailing technology into the less developed countries: the supermarket case. J. Retailing, 57: 5-29.

Goldman, A., 1982. Adoption of supermarket shopping in a developing country: The selective adoption phenomenon. Eur. J. Market., 16: 17-26. DOI: 10.1108/EUM0000000004802

Goldman, A., 2001. The transfer of retail formats into developing economies: The example of China. J. Retail., 77: 221-242. DOI: 10.1016/S00224359(01)00044-6

Goldman, A., R. Krider and S. Ramaswami, 1999. The persistent competitive advantage of traditional food retailers in Asia: Wet markets' continued dominance in Hong Kong. J. Macromarketing, 19: 126-139. DOI: $10.1177 / 0276146799192004$

Goldstein, C., 1990. Counter offensive: Regional supermarket groups invade Taiwan. Far Eastern Econ. Rev., 14: 41-42. 
Hallsworth, A.G. and S. Worthington, 2000. Local resistance to larger retailers: The example of market towns and the food superstore in the UK. Int. J. Retail Distrib. Manage., 28: 207-216. DOI: 10.1108/09590550010319959

Inglehart, R. and W.E. Baker, 2000. Modernization, cultural change and the persistence of traditional values. Am. Sociol. Rev., 65: 19-51.

Kaliappan, S.R., R. Alavi, K. Abdullah and M.A. Zakaullah, 2009. Liberalization of retail sector and the economic impact of the entry of foreign hypermarkets on local retailers in Klang Valley, Malaysia. Int. J. Econ. Manage., 2: 323-342.

Khairul, B.M.N. 2008. Case study: A strategic research methodology. Am. J. Applied Sci., 5: 1602-1604. DOI: 10.3844/ajassp.2008.1602.1604

Marglin, F.A. and S.A. Marglin, 1990. Dominating Knowledge: Development, Culture, and Resistance. 1st Edn., Oxford University Press, Oxford, ISBN: 0198286945, pp: 293.

Moir, H., 1978. Jakarta Informal Sector. 1st Edn., LEKNAS-LIPI, Jakarta, pp: 163.

Moorthy, R., A.C. Er, S. Selvadurai and N. Lyndon, 2011. Bioethics principles in the teaching of climate change. Am. J. Applied Sci., 8: 962-966. DOI: 10.3844 /ajassp.2011.962.966

Muthuveloo, R. and R.C. Rose, 2005. Typology of organisational commitment. Am. J. Applied Sci., 2: 1078-1081. DOI: 10.3844/ajassp.2005.1078.1081

Novel, L., S. Selvadurai, A.C. Er, M.J.M. Fuad and M. Zaidah et al., 2011. Intangible factors influencing gender differences in educational attainment using an abductive research strategy. World Applied Sci. J., 13: 46-52.

Peattie, L., 1987. An idea in good currency and how it grew: The informal sector. World Dev., 15: 851860. DOI: 10.1016/0305-750X(87)90038-6

Poirine, B., 1993. Le développement par la rente dans les petites économies insulaires. Rev. Econ., 44: 1169-1199.

Potter, R.B. and A.T. Salau, 1990. Cities and Development in the Third World. 1st Edn., Mansell, London, ISBN: 0720120667, pp: 200.

Qadeer, M.A., 1974. Do cities 'modernize' the developing countries? An examination of the South Asian experience. Comparative Stud. Soc. History, 16: $266-283$.
Ramezani, S. and S. Hamidi, 2010. Privacy and social interaction in traditional towns to contemporary urban design in Iran. Am. J. Eng. Applied Sci., 3: 501-508. DOI: 10.3844/ajeassp.2010.501.508

Roslin, R.M. and T.C. Melewar, 2008. Hypermarkets and the small retailers in Malaysia: Exploring retailers' competitive abilities. J. Asia-Pacific Bus.s, 9: 329-343.

Selvadurai, S., J. Hamzah, A. Habibah, A. Buang and A.C. Er et al., 2011. The impact of institutional regulation and facilitation on cross-border trade. World Applied Sci. J., 13: 18-22.

Selvadurai, S., 2003. Local-global relations in retail change: Exploring changes in major retail trades in Labuan, Malaysia. University of Sheffield.

Sethuraman, S.V., 1998. Gender, Informality and Poverty: A Global Review.

Smelser, N.J. and R. Swedberg, 1994. The Handbook of Economic Sociology. 1st Edn., Princeton University Press, Princeton, NJ, ISBN: 0691034486, pp: 835.

Stone, K.E., 1995. Competing with the Retail Giants: How to Survive in the New Retail Landscape. 1st Edn., John Wiley and Sons, New York, ISBN: 0471054402, pp: 259.

Suman, N. and M. Psunder, 2007. Mobile computing changing the traditional ways of organizing the construction company. Am. J. Applied Sci., 5: 4247. DOI: 10.3844 /ajassp.2008.42.47

Thomas, J.J., 1995. Surviving in the City: The Urban Informal Sector in Latin America. 1st Edn., Pluto Press, London, ISBN: 0745308279, pp: 156.

Walsh, J., 2010. The street vendors of Bangkok: Alternatives to indoor retailers at a time of economic crisis. Am. J. Econ. Bus. Admin., 2: 185188. DOI: 10.3844/ajebasp.2010.185.188

Worthington, S., 1998. Loyalty cards and the revitalisation of the town centre. Int. J. Retail Distribut. Manage., 26: 68-77. DOI: 10.1108/09590559810206489

Wrigley, N. and M. Lowe, 1996. Retailing, Consumption and Capital: Towards the New Retail Geography. 1st Edn., Longman, Harlow, Essex, ISBN: 0582228247, pp: 352.

Zhang, W.B., 1994. Dynamics of interacting spatial economies. Chaos Solitons Fractals, 4: 595-604. DOI: 10.1016/0960-0779(94)90068-X 